\title{
Indigenous cultural communication of the Mishing Tribe in Changing situation
}

\author{
Namita Pegu \\ Post-Doctoral Fellow, Centre for North East Studies \& Policy Research, Jamia Millia Islamia, New Delhi \\ DOI: 10.29322/IJSRP.11.12.2021.p12029 \\ http://dx.doi.org/10.29322/IJSRP.11.12.2021.p12029
}

\begin{abstract}
Mishing is an ethnic indigenous community mainly found in the north eastern part of India. They reside in the states of Arunachal Pradesh and Assam. They are of mongoloid origin, belong to the Tibeto-Burman family of Indo -Chinese group. This ethnic community have an indigenous communication system, to communicate their culture within the community and to the outsider. They applied religious belief, ritual symbols, dance, song, musical instruments and folklore as a communication agent. The indigenous communication system of the tribe is under threat due to acculturation. The paper will study the affect of acculturation on the IC of the Mishing.
\end{abstract}

Index Terms- acculturation, acculturation theory, ethnic minority, indigenous communication, Mishing, Mibu, Doni-Polo.

\section{INTRODUCTION}

$\mathrm{M}$ ishing ethnic community is of mongoloid origin. This ethnic group is found in the North Eastern part of India in the states of Arunachal Pradesh and Assam. In Arunachal Pradesh state, they are settled in East Siang district, Lower Dibang valley and Lohit. In Assam state, they are mainly settled in Upper Assam districts namely Dhemaji, Lakhimpur, Dibrugarh, Tinsukia, Sonitpur, Jorhat and Golaghat. They are known as riverine tribe in Assam, as they settled in the riverine island of the River Brahmaputra and the bank of its tributaries in Assam.

The indigenous communication system of the Mishing is of tangible, intangible and symbolic in nature. These cultural elements communicate their cultural heritage and collective memory.

\section{Definition \& MeAning OF AcCUlturation}

The concept of acculturation was originally formulated by anthropologist to study group level phenomena on the changes occurred to a group due to cultural changes and adaptation (Boas, 1888). Beside anthropology, acculturation began to apply in other disciplines such as sociology, epidemiology, and inter-cultural psychology. However, its application and approach to study a subject are not coherent among these disciplines (Fu, 2015). Anthropology applied acculturation to study adaptation changes on group level, while psychology on individual level of analysis (Lopez-Class, Castro, \& Ramirez, 2011). Another line of research in "Psychology/psychiatry studies mainly focused on the consequences of culture change (from traditional to modernization or westernization) in third world countries" (Kim, 1979, pp-10). As per their studies, modernization influence cultural changes which increased the psychological disorder. New psychological studies focus on relation of culture or ethnicity and mental health. The anthropological and sociological studies of acculturation approach, mainly based on immigrant group. However, anthropologist studies the changes occurred on the group, while sociologist observed the patter and process of assimilation of minority group with the dominant culture which result in "the dynamics of relationships within and among minority and majority groups" (Kim, 1979, pp- 9). The communication scholars applied acculturation approach to study the interaction of immigrant with the new social-cultural environment (Kim, 1979). Redcliff and other anthropologist recognized acculturation as a subject of study in 1936, and the earliest classical definition is provided by Redfield, Linton, and Herskovits. They defined acculturation as "those phenomena which result when groups of individuals having different cultures come into continuous first-hand contact, with subsequent changes in the original culture patterns of either or both groups." (Redfield, Linton, \& Herskovits, 1936p. 149). In 1953, the Social Science Research Council, formulated the definition of acculturation as "...culture change that is initiated by the conjunction of two or more autonomous cultural systems. Its dynamics can be seen as the selective adaptation of value systems, the processes of integration and differentiation, the generation of developmental sequences, and the operation of role determinants and personality factors" (SSRC, 1953, p. 974). In general, acculturation is a socio-cultural phenomenon, where a group become influence and adopts behaviour and beliefs of another group (Lopez-Class, Castro, \& Ramirez, 2011). In a nutshell, acculturation is a process, which occur due to the interaction, assimilation or connection between two groups, individuals or different cultural societies, which result in collective cultural change to a group or an individual (Nalbandian, 2016).

\section{ACCUlTURATION THEORIES}

To study the process of adaptation of culture of the mainstream by the immigrant, theories have developed to redefine the process of acculturation since 1970. An acculturation theory was developed by Parker in 1978, which had a three-stage known as ecological model. This model consists of- contact, accommodation and assimilation. Parker model defines adjustment of immigrant to new country. According to this model, immigrant contact with mainstream people to accommodate, which result in assimilation and cause of inter-marriage and mixed 
relationship (Balidemaj \& Small, 2019). Berry's theory of acculturation has four acculturation orientation- assimilation, integration, separation and marginalization. In assimilation stage, individuals prefer to interact with other culture daily and maintain a distance from own culture. In integration, individuals participate in mainstream culture but at the same time maintain own culture. In separation individuals tried to distance itself from interaction with other cultural group and tried to keep a hold on own culture. In marginalize individuals are reluctant to maintain relation with other cultural group or show less interest to maintain relation (Berry, 1997). The acculturation model of Mendoza and Martinez is known as assimilation and extension developed in 1981. This model has four types of strategies- cultural resistance, cultural shift, cultural incorporation and cultural transmutation. The acculturation model of Sam and Berry presented that interaction of different cultural groups help to accommodate one another and prevents conflict (Balidemaj \& Small, 2019). Lazarus and Folkman's stress model mentioned that due to acculturation, when an individual is unable to cope up with new situation, acculturative stress occur (Lazarus \& Folkman 1984).

On the basis of these acculturation theories, Mishing scholars tried to study the acculturation process of Mishing tribe. Dr. Jatin Mipun, a scholar, belong to this tribe, was the first one, who done a systematic study on the acculturation process of Mishing tribe. According to Mipun, the acculturation of Mishing has three phases. First phase, Mishing were hill dwellers in Arunachal Pradesh. Second phase, Mishing migrated to the plains of Assam. Third phase, they came in contact with neighbours and adopted their language and religion. This process of acculturation is described as "the growing relationship between the macro (tribal isolated villages), middle (regional economy, culture and polity) and micro (mythology, beliefs, worship, ideology and caste system) levels" (Mipun, 1987, pp 54). He analysed the process of acculturation with the theoretical framework of the concept of the dominant and the week culture of Mead and Herskovitz \& the little and great tradition of Redfield. As per Mead and Herskovitz, the contact of the dominant culture will influence the socio-religious and the traditional practices of the weak culture. It causes the problem of marginality for the community members as well as the community of the week culture tried to find the common elements between the two cultures i.e., dominant and week one. As per Redfield the contact of the little tradition with the great tradition results in acculturation which put an end to the isolation, selfsufficiency and homogenous nature of the community of the little tradition. On the basis of these theoretical framework, the acculturation process of Mishing on religious practices, adaptation of Assamese language, changes on dress, housing pattern, tools and implements have been studied by Mipun. As per the study of Mipun, due to contact with Vaishnava Gosains and Satras, the Mishing converted to Hinduism. After conversion, they followed sects like Bhagavatia, Mahapuruhia, Kewalia, Kalsanghati, Nisamalia and so on. The Sadhu Bura, Hattulas and Bhaktas become the head of all religious activities. They are given this responsibility in the community by the Gosains of Satra after performing proper ritual. They also act as the preacher of Hinduism in the community. Mipun noticed due to acculturation, the position of $M i b u$, lost its special status and villages have Namghar, but there is no Murong Okum. Mishing began to practice sects of Vaishnaism in their own way, by retaining their traditional religious practices along with strict adherence to Vaishnava teaching. In respect to food habit, their staple food is rice. They used to take three meals i.e., rice with meat of fish with herbs and Apong. Due to acculturation new food habits and food articles added in the menu. Beside food habit, Assamese culture is absorbed by the Mishing by offering betel-nut and tea to entertain guest, which is a core of Assamese culture. In regards to language, Mishing are fluent in Assamese as well as adopting language like Hindi to communicate for business dealing. Mishing are open to adopt Assamese language, as it is necessary for not only to communicate with neighbours but also for education. Mipun noticed that few parents are proud for the fluency of Assamese language of their children and few children are not well versed in their own dialect. The ritual conducted by Mishing Bhakats delivered their sermon in Assamese which are adoption of Kirtan, Namghusa and Bhagavat Gita. In regards to house, the pucca houses and Matti Ghar (kuccha house) are built by Mishing in place of traditional platform houses. These types of houses have traditional kitchen and sleeping corner for older generation. The male dress is similar like plain neighbours while only educated women adopted dress of Assamese women, while huge chunk of women still wears traditional dresses. As an inhabitant of Arunachal Pradesh, they had only tools of Jhum cultivation, after migration agricultural tools of wet cultivation are adopted as well as cowshed, buffalo shed and fishing equipment.

Rajeev Doley, applied John Berry theoretical framework to understand the process of acculturation among the Mishing. This theoretical framework organizes acculturation into four stages. This framework explains the issue of retaining traditional cultural identity as well as maintaining positive relation with dominant culture. As per this theory dominant culture (F-first culture) influence the culture of a community (C-contact culture), who are in the process of acculturation.

\begin{tabular}{|l|l|l|}
\hline 1 & $-\mathrm{F}+\mathrm{C}$ & $\begin{array}{l}\text { the first culture is abandoned and the contact } \\
\text { culture is favoured (assimilation) }\end{array}$ \\
\hline 2 & $+\mathrm{F}-\mathrm{C}$ & $\begin{array}{l}\text { the first culture continues and the contact } \\
\text { culture is disfavoured (rejection) }\end{array}$ \\
\hline 3 & $+\mathrm{F}+\mathrm{C}$ & $\begin{array}{l}\text { both the first culture and contact culture are } \\
\text { favoured (integration) }\end{array}$ \\
\hline 4 & $-\mathrm{F}-\mathrm{C}$ & $\begin{array}{l}\text { both the first culture and the contact culture are } \\
\text { disfavoured (deculturation) }\end{array}$ \\
\hline
\end{tabular}

Source: (Doley, 2013, pp-166-168)

The author describes the historical background of the tribe, which is an important episode, without its knowledge the reason of their acculturation will not be understandable. The migration of the Mishing from North-West of China to the plains of Brahmaputra valley, it took about four millennia and, in the process, they had lost certain cultural traits. They had reached about thirteenth century in the Brahmaputra valley. In the plains, they came in contact with communities like Chutiya, Ahom, or British. However, they remain isolated themselves from society and political authority for a considerable time. According to author, the reason for isolation have been their feeling to remain sovereign and unsub missive nature as well as pride for sociocultural norms of the community. Till the seventeen centuries, they were outside the subjugation of Ahom authority, and not 
accustom to the culture as well as lifestyle of the plain neighbours. This stage of Mishing is described as $(+\mathrm{F}-\mathrm{C})$ as per the acculturation theoretical framework. Towards the end of seventeen century, the acculturation process began with the accommodative nature of Ahom government. The Mishings were inducted into civil and military services of the Ahom government. The Mishing soldiers helped the Ahoms to subdue the Nagas, Kacharis and Jayantias. Besides, providing royal services, Mishing began to assimilate with the plain neighbours. They adopted their religion, wet agricultural cultivation, musical instruments, dress, language for communication and so on. In spite of such massive change in socio-religious and cultural changes had not deter them from their traditional way of life, instead they accommodate the adopted culture in their life. This mixing of cultural elements of indigenous culture with contact culture is represented with " $+\mathrm{F}+\mathrm{C}$ ", which means continuation of traditional culture and favour the contact culture. According to him, "-F+C" and "-F-C" are not applicable to Mishing acculturation process (Doley, 2013).

\section{EFFECT OF ACCULTURATION ON ETHNIC MINORITY GROUP}

Studies are conducted to understand the effects of acculturation on ethnic minorities. Such studies provide a clear picture, on the acculturation process of an individual or a group, in respect to cultural adaptation. According to García-Vázquez, "The process of acculturation results in direct lifestyle changes at the individual or group level and is developed in three phases: contact, conflict and adaptation" (García-Vázquez, 1995, pp: 306). Contact is the outcome of interaction of two autonomous group. Conflict occurs when one group dominates the other group or the suppress group resist against the dominance or conflict in terms of belief system. The adaptation has again three forms: adjustment, reaction and withdrawal. In adjustment phase, minority group adopt the cultural behaviour like language, values, custom of the dominant group to reduce conflict. In reaction phase, the minority group express their disagreement on the cultural view of dominant group. To counter their view, they form political organization to promote their culture. In withdrawal phase, the minority group develop themselves as an isolated community to withdraw from the cultural influence of the dominant group. García-Vázquez cited, this acculturation process face by the Latino child and parents in American school (García-Vázquez, 1995). As per Birman \& Addae, acculturation of adult and children immigrant is different. The adult adopts the new cultural behaviour to enter the labour force. However, they maintain relationship with coethnic group, to create a social environment, as they all share similar values and custom. Acculturation has profound impact on immigrant children, as they have not socialized with the culture of their birth nation and they began to interact with the new culture. In the process of acculturation language played the important role. Children between the age of 2 to 12 and adolescent easily acquire the new language, and become a bilingual. Due to the lack of practice, they cannot express complex things in native language. Their knowledge of native language remains consist of simple conversation and described household objects. Behavioural acculturation is more prominent among the children and adolescent. Identity exploration in adolescence is a part of acculturation. They assimilate with the identity of new culture or identify themselves with the native culture or develop a "bicultural" identity (Birman \& Addae, 2015).

\section{RESULT OF ACCULTURATION ON INDIGENOUS CULTURAL COMMUNICATION OF MISHING}

\subsection{World view}

Acculturation has completely affected the world view of Mishing. Their world view mainly surrounds on Abang (ritual song) and Mibu (traditional priest), supreme deities like SediMelo, Doni-Polo, benevolent and malevolent deities as well as host of rituals for blessing and ward off evils from their life. Their life cycle is bounded with their religion. The conversation to Vaishnavism has not affected much to their core religion. However, education and multiplicity of religion has segregated the community in terms of religion. At present Mishing are followers of mainly two religion Vaishnavism (worshipper of Hindu deity Krishna/ Vishnu) \& Christianity. The Doni-Polo (Sun-Moon) is not considered as different religion, as it is the organized form of old beliefs of animistic world view of the Tani tribes of Arunachal Pradesh.

Among all the religions followed by the tribe, Doni-Polo religion is able to hold its influence on the tribe. This religion is originated in Arunachal Pradesh. It is formed under the leadership of Talam Rukbar on $31^{\text {st }}$ December, 1986 in Pasighat of Arunachal Pradesh. The 'Doni-Polo Yelam Kebang' organization is instrumental in the formation of this religious group. After its formation, sub-sects of Tani groups began to follow the teaching of this religion. Mishing being a sub-sect of Tani group also influenced with the teaching of this religion. The 'Doni-Polo Yelam Kebang', made Jonai of Assam, as its base to spread this religion in Assam. This religion is warmly welcome and accepted by Mishing of Jonai. Soon, it began to make its footprints in Silapathar, Dhemaji district, Gugamukh, Lakhimpur district and Majuli district of Assam (mainly Mishing inhabited places). The acceptance and popularity of this religion amongst the tribe, encourage its religious leader to establish a branch of 'Doni-Polo Yelam Kebang' on $10^{\text {th }}$ May, 2003 in Assam. To continue religious activities the 'Doni-Polo Yelam Kebang', formed 'Mekong Kebang', 'Dolung Kebang' and prayer hall. The purpose of 'Mekong Kebang' and 'Dolung Kebang' is to spread the teaching of the religion. Prayer hall is set up to carry on religious affairs like daily prayer (Pegu, 2016).

The reason of mass conversion to Doni-Polo and Christianity, because a fraction of educated Mishing began to question the supremacy of Gosai, head of Satra (religious institute). As per Vaishnavism, followers of a particular Satra have to offer in kinds annually to that particular Satra. Further the Gosai, its associates and Assamese cast lookdown the Mishing, which is against the teaching of Sankerdev, as the Vishnavism of Sankerdev is itself based on equality without any discrimination on the basis of caste. The followers of Doni-Polo believe that teaching of this religion is close to their traditional religion. They believe that this organized religion will be able to check religious conversion as well as originality of the traditional religion in pristine form. The conversion to Christianity and sub-sects of Hinduism \& Vaishnavism is mainly influenced by financial benefit, which is the view of interviewers. 
This multiplicity of religion created confusion in the religious arena of the tribes and shakes the core traditional religion followed by the tribes in generation. The importance of religion in the life of Mishing is that their life is interconnected with religion. Religion conversion means lost of not only religion, ritual but also lost of cultural communication.

Mishing which practiced traditional religion and Vaishnavism, they don't assimilate these two religious' aspects. Traditional follower only performs traditional rituals, no Hindu rites are conducted in their home. There are Mishing villages, who performed both traditional and Hindu rituals like Nam-Kirtan. They observed birth ceremony according to the teaching of Vaishnava Gohai. A purification ceremony is held after three days in case of girl and five days in case of boy. Mother is not allowed to touch anything for seven days. Father of the child sprinkle the holy water on mother, child and the whole home. Holy water is a composition of milk, cow dung, rice, black pulses, tulsi (Hindu sacred plant) and dubari. (Hindu sacred plant) In regards to marriage, they adopted the Assamese marriage song and ritual bath. They performed Nam-Kirtan (chanting of prayer from Bhawagat book) after death of person or for welfare of family. According to Mishing scholar, few of the Mishing rituals like Satjonia, Nojonia and the ritual performer Satola or Bhokat (who perform rituals like Satjonia, Nojonia) are due to the influence of Vaishnavism and the result of assimilation of traditional religion and Vaishnavism. The Doni-Polo follower observed only traditional rituals, but their birth ceremony and death ritual, is performed as dictated in the rule book of their religion. They performed birth purification ceremony after five days. The holy water is sprinkled by the Mibu on mother and child. The holy water is a composition of water, mustard oil, Adi banko (leave consider as sacred by Mishing), tulsi. First, the Mibu sprinkle the holy water then rice and the mother has to drink the holy water and keep the rice inside the mouth. Two lamps are lightened in the honour of traditional deities Keum-Kero, Sedi-Melo, Bamo-Boo, Doni-Polo and Ane-Abu. These lamps are lit in front of a photograph of a 'Lemo'. Lemo is a basically an artistic representation of Sun, which symbolize Doni-Polo. One coin is also kept near the lamp. According to Doni-Polo believers, these deities symbolize creation of universe and this ritual symbolically represent mother as creator. Prayer on Mishing language is singed. After that all family members bow down before the Lemo for blessing and the Mibu sprinkle holy water and rice on them. The name ceremony of the child is also done in this same ceremony. Their death ritual is an assimilation of traditional ritual and as dictated in their rule book. According to Prabhat Milli, after the death of a person, the Doni-Polo followers, observed all the norms as followed in the traditional system. They only put a bamboo post on the Merum (cooking hearth), which is not observed by other Mishing. The Doni-Polo follower, first keep a leaf of Adi Banko at the centre of the Merum. On this leaf, a bamboo post of 4 meter is inserted. On the top of bamboo post a ginger is kept and its two sides are tied with a broad leaf called Taku. The catholic Mishing converts belief that Christianity, does not alienate them from Mishing culture and religion. Instead, their father encourages them to integrate Mishing tradition with catholic Christian religion. They can eat food items offered during Mishing ritual, which is a taboo for Mishing followers of Krishna guru, a Vaishnava sect. According to them, catholic Christians followed all Mishing tradition and culture, only difference is that their birth, marriage and death ritual are conducted by father in the church.

In a nutshell, it can be said that acculturation is responsible for multiplicity of religion amongst Mishing. The integration and assimilation will wipe out the core religion, and lost of religion means traditional outlook and traditional way of communication is affected with unrepairable manner.

\subsection{Position of Mibu}

In the previous chapter, discussed the spirituality attached with Mibu. Mibu is a living tradition which represent world view of the Mishing. The position, respect, belief, and trust on Mibu deteriorated due to acculturation. Mr. Prabhat Milli, an interviewer said, the authenticity of new generation Mibu are doubtful. According to him, the new generation Mibu does not has such knowledge. Still a handful of Mibu are found in the society.

The main reason behind the deterioration of the position of Mibu is education. Parents wants their children to be an educated person. So, when a boy shows the sign to become Mibu, this process is stopped forcefully, by giving food items, which are taboo for Mibu. Mibu cannot eats certain foods, it is believed that such foods disrepute the link of spiritual world with the Mibu. Hence, the number of Mibu is drastically decreasing and it is one of the reasons.

In early days Mibu is the only hiller for the bedridden or critically ill patient. In the previous chapter, it is mentioned, how Mibu cure person by using his hilling power. However, at present his services is replaced by doctors and modern medicine.

The Porag festival cannot be performed without Mibu. However, many villages discontinued this festival. So, his services do not require.

The Mibu profession does not provide any monetary benefit to the person. As he is offered with kinds, not cash for his services. Present materialist world require money to meet basic needs of life.

\subsection{Festivals}

The main festivals celebrated by Mishing are only Ali-AiLigang (harvest festival) and Porag (harvest festival). Due to acculturation non-Mishing festival become an integral part of Mishing culture. The non-Mishing festival like Rongali Bihu (spring festival), Magh Bihu (post-harvest festival) and Kati Bibu (pre-harvest festival) are celebrated with great pomp by the community. The religious festival like Janmastami, (celebration of birth anniversary of Hindu god Krishna), Rasleela are also celebrated in few Mishing villages. The changes in the festivals of the surveyed villages.

\subsubsection{Rasleela}

Rasleel festival is held in the month of October-November. This festival is celebrated only in the Mishing villages of Majuli district of Assam. This festival is observed in Satras like Dakhinpat \& Garamur Satras, and in few villages of Majuli. Rasleela is a theatrical representation of Krishna's life on stage. It depicts Krishna's birth, killing of demons, eternal love of KrishnaRadha, dance and fun with Gopis and end with the killing of his maternal uncle Kansh.

The first Rasleela is performed in Dakhinpat Shatras in 1840 A.D. The tradition of stage performance of Rasleela is promoted by Pitambardeva Goswami of Garamur Shatras in 1934. Initially all the female characters are performed by males. He allowed the girls to participate and perform characters in Rasleela from 1950. 
Initially all the Mishing of Majuli district followed the Vaishnava teaching of Sesa Satra, situated in Jorhat Koranga. In the mid of 40's the Pame families of Borgoya village, under the guidance of Tarun Ch. Pamegam, the first renowned writer of Mishing and the first Mishing to become the vice-president of Asom Sahitya Sabha in 1975, became disciple of Bor Alengi Satra of Majuli.

The tradition of Rasleela in Mishing village was started by the Chitadarchook village of Majuli. This Mishing village performed Rasleela in their village for two years continuously, after that it discontinued this practice.

The first Rasleela of Borgoya village was held in 1974 under the leadership of Taun Ch. Pamegam and Pitambar Dev Goswami, Sattradhikar of Garamur Bor Satra. Since 1974, the village performed Rasleela every year. This Rasleela is special, as all the characters, musician, direction, decoration of the Rasleela is acted and done by the Mishing of the Borgoya village. At present, this Rasleela draw a huge crowd each year.

Beside Borgoya, Mishing village like Nayabazar and Jengrai performed Rasleela. These Rasleela spreads the teaching of Vaishnava through the life of Krishna and displaying his greatness as a deity. The Rasleela of Borgoya village used Assamese as medium of communication with audience, while in Nayabazar and Jengrai, all dialogue and songs are in Mishing. This kinds of Rasleela amuse Mishing villagers, who are more comfortable in their mother tongue.

\subsubsection{Ali-Ai-Ligang}

This harvest festival is celebrated in all the four surveyed villages. However, acculturation has brought changes in this festival. In early days, it is a family and social affair. Each family and village performed with utmost pomp for good harvest. At present, certain custom associated with the festival, became irrelevant for the people. The custom of clearing a plot of land, sowing seeds in the next day and offering rice beer in the Merum are hardly practiced. Instead, the whole community gather in the Murong Okum (youth dormitory) or an open public place. A piece of land is cleared in the open public place or in the open area of Murong Okum, where ritual related to agriculture is performed, and all the villagers dance Gumrog-Soman (a type of traditional dance), around the alter. Ritual related to offering rice beer, is performed on the Merum of Murong Okum. Then it is followed by cultural program and community feast.

Gumrog-Soman is the most integral part of Ali-Ai-Ligang. Mishing believe that sound of musical instrument like drum and Lene-Marbang (gong) as well as sound produced by foot movement of female dancer will keep away pest from agricultural field, and the farmer have a bumper crop. So, the villager dance around the ritual alter. In early days, youth of the villager performed Gumrag-Soman in each house of the village, and every household entertain the troupe with special foods prepared for this festival, which is consist of Purang (boiled rice packed in leaves), pork meat cooked with leafy vegetables and black colour rice beer. At present Gumrag-Soman is performed in stage. Further various cultural programs are organised by the organizing committee to entertain the villager. However, the community feast cuisine is remained same.

Due to acculturation, this festival turned into a stage performance. Only renowned personality like singer, dancer, musician of the community and trained troop of dancer get the chance to showcase their talent. Such personality demand payment for performance and their logistic have been arranged by the community. To meet these expenses, the organizing community take donation from established politician and from the villager. In return, the committee felicitate politician and person who provided handsome donation. Politician used such platform to spread their political propaganda. Another major change is eruption of VIP culture in this festival. The eating arrangement is divided into two parts- VIP area is reserved for only politician, dignified invited personality to the festival and committee member and one is for commoner, where villager can dine.

Before acculturation each villager from old to toddler dance and sing, there is no requirement of perfection. Further, equality is the basic foundation of the community, which is losing due to acculturation.

\subsubsection{Porag festival}

This post-harvest festival is not observed in all the Mishing villages. The reason is enormous cost involved in the festival as well as acculturation.

Due to education and job purpose, most of the youth are in towns and metro cities. Without the village youth, this cannot be performed. This is the present situation in the villages. The leftover handful youth, busy in eke out income through various means, like self-employment. They don't depend on agriculture. Therefore, youth are busy enough for livelihood and education. Further, the Mishing villages faced the problem of recurrent flood problem. Due to population explosion, they cannot shift the entire village to a new area, which they used to do pre-independence of India. This shifting of villages enables them to cope with the problem of flood, deforestation or depletion of resources.

The Mibu dagnam (ritual song and dance perform by traditional pries), the central theme of this festival is now performed in stage in cultural functions. In true sense, it is losing the charm of the festival. If it goes this manner, this festival will be lost forever.

\subsubsection{Bihu}

The three Bihu-Rongali Bihu, Magh Bihu and Kati Bihu are an integral part of Mishing culture, which is the result of acculturation. In the surveyed villages, it is found that in Magh Bihu, like fellow Assamese neighbours, they prepared gila pitha, til pitha like sweet dishes from rice. They have synthetised this Bihu with Mishing culture. During this Bihu, they entertained guest with Purang, Apong and a dish made of potato. In Rongali $B i h u$, they wear traditional dresses and perform Gumrag-Soman or Assamese Bihu. Gumrug is traditionally perform in Ali-ailignag, but nowadays it is performed in Rongali Bihu and in any cultural programme. Kati Bihu is mainly observed in Vaishnava Mishing villages, due to the strong influence of Vaishnavism. The villager simply lit a candle in the agricultural field for good harvest.

\subsection{House}

Mipun mentioned on his book, about the changes occurred in the traditional house type of Mishing. He observed that economical wealthy Mishing built pucca houses with a traditional kitchen (Mipun, 1987). This is the scenario of house in all the Mishing villages. Only the interior and flood affected Mishing villages have traditional house. The practice of ten-layer concept of traditional house is not practiced in most of the villages.

\subsection{Murong Okum}

The affects of acculturation can be seen in the backbone of Mising socio-cultural institute, Murong Okum. The purpose of 
Murong Okum gradually change with time. In early days, the youth of the village used it as a training institute. The unmarried youth after having dinner in respective home, gather in the Murong Okum to practice musical instruments, gossip, and protect the village from outside invader by patrolling whole night. The senior boys train the junior boys. No such training required due to modern education system. Further, the village required no patrolling as the fear of sudden raid from animals and humans are irrelevant.

The village head and male elders gather in the Murong Okum to decide legal matters as well as customary laws of the community. This is still in practice.

At present time, the village youth built Murong Okum only in time of Porag festival, and some villages have permanent building i.e., Murong Okum.

\subsection{Dance}

Due to acculturation, certain dance forms became obsolete like Lata Soman or Pipal Soman. Only the Gumrug-Soman dance form is kept alive, due to its necessity, during Ali-ai-Ligang. However, dance forms 'Selloya' and 'Lareli' are on the path to revival, due to the initiative of TMPK (Takam Mishing Parin Kebang-All Mishing Student Union) and Dirbu Kabang, a wing of Agam Kebang. They organized training camp as well as made arrangement to display their skill in cultural program.

\subsection{Music}

Music is the lifeline of Mishing culture and day to day life. Acculturation has a considerable impact on the music of Mishing tribe. Only Oinitom (love song) is in practice, while rest of the genres are faded away. The religious song called 'Abang' can be sing only by the Mibu, and its number is itself shirking. Further, as per the interviewers, the authenticity of new generation Mibu is doubtful. The children don't play games, which are played by their forefather, so nursery songs associated with these games are lost. Further, the system of Nebung (baby siter) is become obsolete in the society, so lullabies sing by the Nebung will lost in near future. The tradition of Kaban (sorrowful song), is continued in few interior villages.

The Oinitom survive, because alteration to Oinitom is warmly welcome by the community. However, it is affecting the original form of Oinitom. To resolve this problem, Oinitom is divided into two forms-Anu Nitom (new song) \& Oinitom. The rule has been set that the original form of Oinitom has to be maintained by the singer, composer and lyricist, no alteration can be allowed, while no such rule will be applicable for Anu-Nitom. The term itself define 'Anu-Nitom' means new song.

Due to acculturation, western music, Bollywood songs, Assamese songs and religious song like Borget (religious song of Vaishnavism) are also become integral part of music life of Mishing tribe.

\subsection{Musical Instrument}

The community have retained only few musical instruments, which are of utmost important, without which festival, ritual or important social obligation cannot be performed. One such musical instrument is Lc:nong: Marbang. Rest of the traditional musical instruments are obsolete. The musical instrument used at present are- Lc:nong: Marbang, Dumdum(drum), Lu:Pi (flute) etc.

\section{OUTCOME OF THE RESEARCH}

In regards to acculturation of Mishing, only the integration of Berry's acculturation theory is applicable, as mentioned by Doley in his research. Beside the integration, a stress is found in older generation, female and economically poor individual, who find it difficult to accommodate with the change in the society. This section prefers to maintain the core culture, inherited from ancestor. This section is the backbone of Mishing, fighting for ethnic identity by forming political and cultural organization.

\section{CONCLUSION}

The process of acculturation is slow within the community during the neo-vaishnava movement and the Ahom policy 'Ahomisation' to integrate the mongoloid tribes. However, this assimilation helped the process of acculturation among the community. They adopted Assamese language as a medium of communication and converted to Hindu religion (Bora, 2014). The post-independence development policies have far reached impact on the acculturation process of Mishing. For individual development and community well-being Mishing began to adopt modern education system, Hindu ritual, life-style of the plain neighbours, culture, custom and so on. In the process either they discarded their native way of life or modified it, to adjust in the new culture. They began to lose native language speaker, certain rituals, traditional games, musical instruments, and it affects on the world view of the tribe, which is the basis of their identity, culture and a way of life.

\section{ACKNOWLEDGEMENT}

I am grateful to Indian Council of Social Science (ICSSR), New Delhi for providing financial support for the study.

\section{REFERENCES}

[1] Anon. 1935. Acculturation: An Exploratory Formulatiolz. The Social Science Research Council Summer Seminar on Acculturation.

[2] Balidemaj, Albina and Small, Mark. 2019. The effects of ethnic identity and acculturation in mental health of immigrants: A literature review. International Journal of Social Psychiatry 65: 643-55.

[3] Berry, John W. 1997. Immigration, Acculturation, and Adaptation. Applied Psychology: An International Review 46 (1):5-68, Queen's University, Ontario.

[4] Birman, D. \& Addae, D. 2015. "Acculturation," in Transitions: The development of children of immigrants, pp. 122-141. NYU Press

[5] Boas, F.1888. The aims of ethnology. Race, language, and culture, pp. 62838. New York: Macmillan.

[6] Doley, Rajiv. 2013. "Acculturation and the Misings of the Brahmaputra Valley,” in GRA - Global Research Analysis, pp. 166-168.

[7] García-Vázquez, Enedina. 1995. Acculturation and academics: effects of acculturation on reading achievement among Mexican American students. The Bilingual Research Journal 19: 305-15.

[8] Kim, Young Y.1979. Need for a Unified Theory of Acculturation: A Critical Review and Synthesis. Paper presented at the Annual Conference of the American Psychological Association, New York.

[9] Lazarus, R.S., and Folkman, S. 1984. Stress, appraisal and coping. New York: Springer.

[10] Lopez-Class, Maria., Castro, Felipe González, and Ramirez, Amelie G. 2011 Conceptions of acculturation: A review and statement of critical issues. Social Science \& Medicine. (Doi: 10.1016/j.socscimed.2011.03.011) 
[11] Fu, Kefeng. 2015. A Brief Literature Review on Acculturation Strategies of Overseas Students. (Doi:10.5539/elt.v6n8p121)

[12] Mipun, J. 1987. The Mishings of Assam: Development of a New Lifestyle. New Delhi: Gian Publishing House.

[13] Nalbandian, Nyrie. 2016. Longing and belonging: a study of acculturation and enculturation of ethnic australian students and its influences on psychosocial constructs. Ph.D. dissertation, Western Sydney University, Australia.

[14] Pegu, Juwel. 2016. Mising Samaj Sanskriti Aru Parampara. Lakhimpur: Ranganoi Prakashan.
[15] Redfield, R., Linton, R., and Herskovits. 1936. M.T. Memorandum for the study of acculturation. American Anthropologist 38:149-52.

\section{AUTHORS}

First Author - Namita Pegu, Post-Doctoral Fellow, Centre for North East Studies \& Policy Research, Jamia Millia Islamia, New Delhi, Namitapeguoo21@gmail.com 